\title{
Methodological Approaches towards Assessing the Efficacy of a Region's Budgetary/Taxation Policy
}

\author{
Basir Khabibovich Aliev ${ }^{1}$, Khaibat Magomedtagirovna Musaeva ${ }^{1} \&$ Magomed Magomedovich Suleymanov $^{1}$ \\ ${ }^{1}$ Federal state educational institution of higher professional education "Dagestan state University", Republic of \\ Dagestan, Makhachkala, Gadjieva street 43 "a", Russian Federation \\ Correspondence: Basir Khabibovich Aliev, Federal state educational institution of higher professional education \\ "Dagestan state University", Republic of Dagestan, 367000, Makhachkala, Gadjieva street 43 "a", Russian \\ Federation. Tel: 79-28-837-5570. E-mail: fefnews@mail.ru
}

\author{
Received: July 18, 2014 Accepted: July 30, 2014 Online Published: November 27, 2014 \\ doi:10.5539/ass.v10n24p35 URL: http://dx.doi.org/10.5539/ass.v10n24p35
}

\begin{abstract}
This article provides an analysis of existing methodologies for assessing the efficacy of a region's budgetary/taxation policy and identifies their strengths and weaknesses. The author argues in favor of that the efficacy of a region's entire budgetary/taxation policy can be assessed by the efficiency of the activity of the executive authorities in the above focus areas based on the correlation of goals set and results achieved. An objectively set criterion of the efficacy of a region's budgetary/taxation policy is the minimum degree of chasms between goals set and results achieved. The author proposes quantitatively measured indicators as criteria of the efficacy of budgetary/taxation policy. On the strength of the analysis conducted, the author proposes a way to assess the efficacy of a region's budgetary/taxation policy, which is based on systematizing an aggregate of measures with a breakdown into structural determinants and calculating the integral coefficient, which, compared with existing methodologies, makes it possible to give an integral and structured, in terms of key blocks, assessment of the efficacy of a region's budgetary/taxation policy both over time and through comparison with other regions and increase the validity and accuracy of the assessment for working out practical recommendations. The author chooses as the basis of his calculation of the integral indicator of the efficacy of a region's budgetary/taxation policy the method of distances, which is based on taking account of the proximity of objects under examination to the touchstone object by indicators compared.
\end{abstract}

Keywords: methodology, efficacy, budgetary/taxation policy, integral coefficient, method of distances

\section{Introduction}

The objectives of the new stage in the development of budgetary/taxation decentralization and inter-budget relations, which have been set out in the Budget Message of the President of the RF (Aliyev \& Suleimanov, 2013a), the Budget Strategy for the Period through to 2023 (Aliyev \& Suleimanov, 2013b), and the Major Focus Areas of Taxation Policy for 2013 and for the Target Period of 2014 and 2015 (Berezdivina), substantiate the need for expanding regions' self-reliance and responsibility for the sustainable growth of the regional economy and the population's living standards. A number of functions of regulating social-economic processes are shifting from the federal to the regional level; there is an augmentation of the role of regions' budgets in ensuring the progressive dynamics of regional economic complexes and the social sphere. In these conditions, priority significance is being assigned to enhancing the state regulation of regional development and as part of it-boosting the efficacy of regions' budgetary/taxation policy (Treisman, 2004, p. 820).

The formation of effective regional budgetary/taxation policy oriented towards stimulating territorial reproductive processes is an overriding objective of any federal state (Oates, 1972, p. 213). In Russia, resolving this objective is especially complicated due to the specificity of the federal configuration and substantial interregional differences in the level of social-economic development, natural/climactic conditions, national, historical, and other characteristics (Suleimanov, 2013, p. 9). With all the significance of transformations being carried out, the state's present-day budgetary/taxation policy does not facilitate remediating imbalances in regions' social-economic development-due, above all, to the fact that it does not stimulate one's interest in the development of one's own financial/resource potential and expansion of the taxable base. Boosting the efficacy of regions' budgetary/taxation policy remains one of the issues poorly researched, which need further theoretical conceptualizing and call for working out a 
methodological toolbox for assessing it.

Boosting the efficacy of regions' budgetary/taxation policy remains a crucial priority in the activity of the authorities of the Federation's constituents (Musaeva, 2013, p. 645). As part of optimizing the functions of state governance and boosting their efficiency, there is a need for working out a methodology for assessing the efficacy of regions' budgetary/taxation policy. The efficacy of a region's budgetary/taxation policy is determined by the correlation of goals set and results achieved (Aliyev \& Suleimanov, 2013a, p. 48). An objectively set criterion of the efficacy of a region's budgetary/taxation policy is the minimum degree of chasms between goals set and results achieved is an objectively set criterion of the efficacy of a region's budgetary/taxation policy. Note that the efficacy of a region's budgetary/taxation policy is predicated on the supposition that every managerial decision is a consequence of the search for the best variant among a set of possible ones (Kravtsova et al., 2014, p. 10). In this case, the best are variants that ensure improvement in the population's quality of life and the social-economic situation in the region.

Crucial focus areas of a region's budgetary/taxation policy are budget revenue collection, fulfilling budget obligations, and managing the budget deficit and the national debt (Aliyev \& Suleimanov, 2013b, p. 45). The efficacy of a region's entire budgetary/taxation policy can be assessed by the efficiency of the activity of the executive authorities in the above focus areas. The following quantitatively measured criteria can be proposed as criteria of the efficacy of budgetary/taxation policy:

a) the degree to which budget revenue, as a whole, is and taxes, in particular, are collected;

b) the degree to which budget obligations are fulfilled;

c) the size of the budget deficit and the pace at which the national debt is growing;

d) the volume of financial resources allocated for servicing the state budget;

e) the degree to which the budget deficit is monetized;

f) the dynamics of the Gross Domestic (Regional) Product;

g) the unemployment level;

h) the degree to which legislative and equivalent acts on the budget are fulfilled (Laptev, 2010, p. 154).

\section{Methods}

Table 1. Indicators characterizing the efficacy of regions' budgetary/taxation policy

\begin{tabular}{|c|c|}
\hline Indicators & Economic content \\
\hline \multicolumn{2}{|c|}{ Indicators reflecting the efficacy of formation of revenue } \\
\hline $\begin{array}{l}\text { The tax and non-tax revenue } \\
\text { fulfillment coefficient }\left(\mathrm{I}_{1}\right)\end{array}$ & $\begin{array}{l}\text { The coefficient determined by the ratio between actual revenue over a certain } \\
\text { period of the current year and target revenue. }\end{array}$ \\
\hline $\begin{array}{l}\text { The share of debt on taxes and } \\
\text { levies in the total amount of } \\
\text { tax payments }\left(\mathrm{I}_{2}\right)\end{array}$ & $\begin{array}{l}\text { es and the total volume of tax payments is one of } \\
\text { mining the quality of the operation of the region's } \\
\text { urn, is directly linked with the formation of the }\end{array}$ \\
\hline $\begin{array}{l}\text { The share of one's own } \\
\text { revenue in the total volume of } \\
\text { revenue }\left(\mathrm{I}_{3}\right)\end{array}$ & $\begin{array}{l}\text { Determines the degree to which the RF constituent is independent of financial } \\
\text { support from the federal center. Large dependence on receipts from budgets of } \\
\text { other levels has a negative effect on the region's competitiveness, since there } \\
\text { are no guarantees that these funds will come in time and in full. }\end{array}$ \\
\hline $\begin{array}{l}\text { of tax receipts in the } \\
\text { GRP }\left(\mathrm{I}_{4}\right)\end{array}$ & Characterizes the level of the region's tax potential and tax load. \\
\hline \multicolumn{2}{|c|}{ Indicators reflecting the efficacy of formation of outlays } \\
\hline $\begin{array}{l}\text { The share of funds directed } \\
\text { into budgets of other levels } \\
\left(\mathrm{I}_{5}\right)\end{array}$ & $\begin{array}{l}\text { Determines the size of finan } \\
\text { constituent has to provide to } \\
\text { the higher the risk of the regi }\end{array}$ \\
\hline $\begin{array}{l}\text { The coefficient of covering } \\
\text { budget outlays with tax } \\
\left.\text { revenue ( } \mathrm{I}_{6}\right)\end{array}$ & $\begin{array}{l}\text { ties to make good, } \\
\text { ns provided for by }\end{array}$ \\
\hline $\begin{array}{l}\text { The share of outlays on } \\
\text { servicing the debt of the } \\
\text { Federation's constituent in the } \\
\text { budget outlays of the }\end{array}$ & $\begin{array}{l}\text { et. Increases in the na } \\
\text { itiveness. }\end{array}$ \\
\hline
\end{tabular}




\section{Indicators \\ Federation's constituent $\left(\mathrm{I}_{7}\right)$ \\ Indicators assessing the bala \\ The coefficient of the budget's financial dependence $\left(I_{8}\right)$}

The level of the region's fiscal capacity $\left(\mathrm{I}_{9}\right)$

The ratio between the region's budget deficit and the volume of revenue not inclusive of financial support from the federal budget $\left(\mathrm{I}_{10}\right)$

\section{Economic content}

\section{cedness and sustainability of the regional budget}

Indicates what share in the total amount of revenue in the consolidated budget of the RF constituent is accounted for by constituent tax revenue from federal taxes and levies plus financial support from the federal budget in the form of dotation's and subsidies. The higher the value of this indicator, the higher is the risk associated with a possible precipitous decrease in revenue, as a result of reduction in financial support.

Determines the ratio between expected budget revenue per single resident, which can be obtained by the region's budget based on the development level and structure of the region's economy, the size of the population, social-economic, geographic, climactic, and other objective factors impacting on the cost of providing one and the same volume of budget services on a per single resident basis.

Characterizes the measure of the region's ability to meet budget obligations. If the region has a large budget deficit, additional funds have to be engaged to cover it, which results in an increase in debt.

In our view, the assessment of the efficacy of a region's budgetary/taxation policy should be conducted based on the following indicators:

- those reflecting the efficacy of formation of revenue;

- those reflecting the efficacy of formation of outlays;

- those reflecting the balancedness and sustainability of the regional budget.

The following indicators should be employed as universally accepted (i.e. available in one form or another in each methodology) among key ones: the coefficient of fulfillment of tax and non-tax revenue, the share of debt on taxes and levies in the total amount of tax payments, the share of one's own revenue in the general volume of revenue, the share of tax receipts in the volume of GRP, the share of funds directed into budgets of other levels, the coefficient of covering budget outlays with tax revenue, the share of outlays on servicing the debt of the Federation's constituent in the outlays of the budget of the Federation's constituent, the coefficient of the budget's financial dependence, the level of the region's fiscal capacity, the ratio between the region's budget deficit and the volume of revenue not inclusive of financial support from the federal budget (Table 1).

Table 2 provides source data for calculating the indicators of the efficacy of the budgetary/taxation policy of the Republic of Dagestan over 2009-2013.

Table 2. Baseline data for calculating the indicators of the efficacy of the budgetary/taxation policy of the Republic of Dagestan over 2009-2013, million rubles

\begin{tabular}{llllll}
\hline Indicators & 2009 & 2010 & 2011 & 2012 & 2013 \\
\hline Revenue, total & 38782.3 & 52614.3 & 64422.8 & 62407.2 & 63306.6 \\
Tax revenue & 8372.9 & 14281.7 & 13733.1 & 16439.1 & 21420.5 \\
Non-tax revenue & 0.3 & 0.3 & 0.8 & 0.4 & 0.3 \\
Non-repayable receipts & 30409.1 & 38332.3 & 50688.8 & 45967.7 & 41885.8 \\
Subventions & 4195.7 & 1983.6 & 3140.8 & 3957.6 & 2161.7 \\
The amount of debt on taxes & 1058.0 & 1281.0 & 2306.0 & 4186.0 & 6662.0 \\
Outlays, total & 38165.7 & 49651.4 & 67603.7 & 64058.5 & 64883.1 \\
The budget deficit & 616.6 & 2962.8 & 3180.9 & 1651.2 & 1576.4 \\
Outlays on servicing the debt of the Federation's & 3.4 & 5.6 & 4.8 & 17.2 & 31.8 \\
constituent & 225335.2 & 219812.1 & 270121.1 & 292130.1 & 315500.5 \\
The Gross Regional Product & & & &
\end{tabular}

Compiled based on data from the Ministry of Finance of the Republic of Dagestan 
On the strength of the data provided, let us calculate the major indicators of the efficacy of the region's budgetary/taxation policy (Table 3). The choice of a set of indicators is a complex task, since an excessive number of them can result in the loss of simplicity and univocacy in the result obtained, while, on the contrary, a small number of indicators will impair the integrated approach and result in overlooking certain factors impacting on the subject of the study.

We have chosen as the basis of our calculation of the integral indicator of the efficacy of the budgetary/taxation policy of the Republic of Dagestan the method of distances, which is based on considering the proximity of objects under examination to the touchstone object by indicators compared. Therefore, it is important to determine the touchstone object in the right way. In theory, it is normally recommended designating as the touchstone objects a nominal object with the best values/elements by the indicators of the source system.

Table 3. A matrix of indicators for calculating the integral indicator of the efficacy of the budgetary/taxation policy of the Republic of Dagestan over the period of 2009-2013

\begin{tabular}{lllllllllll}
\hline Indicators & $\mathrm{I}_{1}$ & $\mathrm{I}_{2}$ & $\mathrm{I}_{3}$ & $\mathrm{I}_{4}$ & $\mathrm{I}_{5}$ & $\mathrm{I}_{6}$ & $\mathrm{I}_{7}$ & $\mathrm{I}_{8}$ & $\mathrm{I}_{9}$ & $\mathrm{I}_{10}$ \\
\hline Year & & & & & & & & & & \\
2009 & 0.97 & 0.12 & 0.89 & 0.03 & 0.32 & 0.21 & 0.001 & 0.978 & 0.64 & 0.07 \\
2010 & 0.99 & 0.08 & 0.96 & 0.06 & 0.29 & 0.28 & 0.001 & 0.969 & 0.62 & 0.20 \\
2011 & 0.94 & 0.16 & 0.95 & 0.05 & 0.31 & 0.20 & 0.001 & 0.973 & 0.54 & 0.23 \\
2012 & 0.92 & 0.25 & 0.93 & 0.05 & 0.35 & 0.25 & 0.002 & 0.969 & 0.61 & 0.10 \\
2013 & 0.95 & 0.31 & 0.96 & 0.06 & 0.34 & 0.33 & 0.004 & 0.964 & 0.63 & 0.07 \\
Stimulant+, destimulant - & + & - & + & + & - & + & - & - & + & - \\
Touchstone/Standard & 1 & 0.2 & 1 & 0.5 & 0.3 & 1 & 0.15 & 0.3 & 1 & 0.15 \\
\hline
\end{tabular}

Thus, if an indicator included in the system for assessing the efficacy of budgetary/taxation policy is a stimulant by content, one should designate as the indicator of the touchstone the maximum value in the source matrix of data, i.e., $x_{i, m+1}=\max \left(x_{i j}\right), i=1, \ldots, n ; j=1, \ldots, m$. In this case, if an indicator included in the system for assessing the efficacy of budgetary/taxation policy is a destimulant by content, one should as the indicator of the touchstone the minimum value in the source matrix of data, i.e. $x_{i, m+1}=\max \left(x_{i j}\right), i=1, \ldots, n ; j=1, \ldots, m$.

In some cases, one considers as the touchstone object such an object whose indicators' values are equal to the mean arithmetic levels of indicators in the aggregate under study (Brennan, 2008: 65). However, in an aggregate of economic objects dominated by asymmetric distributions the arithmetic mean in the capacity of a typical touchstone object loses its value. In our case, it is this consideration that triggered our choice of method for the computation of the integrated assessment.

We consider it most correct to conduct the computation of the integrated assessment of the efficacy of budgetary/taxation policy using the Euclidean distance formula from the point of the touchstone to the specific values of the indicators of objects under assessment. For each object, we calculate the distance to the touchstone using the following formula:

$$
K_{j}=\left[\sum_{i=1}^{M}\left(1-\frac{x_{i j}}{x_{i, m+1}}\right)^{2}\right]^{1 / 2}
$$

where

$K_{\mathrm{j}}$ is the rating of the period with the highest efficacy of the region's budgetary/taxation policy;

$\mathrm{X}_{\mathrm{ij}}$ denotes the indicators of the efficacy of the region's budgetary/taxation policy over the i-period;

$\mathrm{X}_{\mathrm{i}, \mathrm{m}+1}$ denotes the indicators of the touchstone values of the j-indicators of the efficacy of the region's budgetary/taxation policy over the i-period.

One should note the substantiatedness of the distance between the values of the indicators of a specific period not inclusive of those particular aspects of budgetary/taxation policy does not have the same effect on its efficacy. 
Considering that it is incommensurable indicator units selected for the assessment of the efficacy of the regions budgetary/taxation policy that are the elements of the distance and there are substantial differences between their levels (0.001 to 0.99), the use of simple methods of computing the integrated assessment will result in the absorption of indicators with a low level. Therefore, in computing the integrated assessment, which characterizes the efficacy of the region's budgetary/taxation policy, one, in our opinion, needs to consider the indicators as equal, of similar significance. To remediate the incommensurableness of the indicators for assessing the efficacy of the region's budgetary/taxation policy, let us conduct the normalization of the values of the indicators in the source matrix through dividing the values of the indicators $\mathrm{x}_{\mathrm{ij}}$ by the values of the touchstone object $\mathrm{xi}, \mathrm{m}+1$, and illustrate the results in Table 4.

Table 4. A matrix of the normalized values of the indicators for the assessment of the integral indicator of the efficacy of the budgetary/taxation policy of the Republic of Dagestan

\begin{tabular}{lllllllllll}
\hline Indicators & 1 & 2 & 3 & 4 & 5 & 6 & 7 & 8 & 9 & 10 \\
\hline Year & & & & & & & & & & \\
2009 & 0.97 & 0.6 & 0.89 & 0.06 & 1.07 & 0.21 & 0.007 & 3.26 & 0.64 & 0.47 \\
2010 & 0.99 & 0.4 & 0.96 & 0.12 & 0.97 & 0.28 & 0.007 & 3.23 & 0.62 & 1.33 \\
2011 & 0.94 & 0.8 & 0.95 & 0.1 & 1.03 & 0.20 & 0.007 & 3.24 & 0.54 & 1.53 \\
2012 & 0.92 & 1.25 & 0.93 & 0.1 & 1.17 & 0.25 & 0.013 & 3.23 & 0.61 & 0.67 \\
2013 & 0.95 & 1.55 & 0.96 & 0.12 & 1.13 & 0.33 & 0.027 & 3.21 & 0.63 & 0.47 \\
\hline
\end{tabular}

By arranging the values $K_{j}$ in ascending order, we obtain an integrated ranking of the objects (in our case, periods), with the object distanced from the touchstone the least getting the highest rating (first place), etc. An example of computing the efficacy of the region's budgetary/taxation policy based on an integrated assessment for the year 2012 is illustrated in Table 5.

Table 5. Calculating the integral indicator of the efficacy of the budgetary/taxation policy of the Republic of Dagestan for 2012

\begin{tabular}{|c|c|c|c|c|}
\hline Indicators & $\begin{array}{l}\text { Actual } \\
\text { value }\end{array}$ & $\begin{array}{l}\text { Normalized } \\
\text { value }\end{array}$ & Deviation & Calculation \\
\hline $\begin{array}{l}\text { 1. The tax and non-tax revenue fulfillment } \\
\text { coefficient }\end{array}$ & 0.92 & 0.92 & - & $(1-0.92)^{2}=0.0064$ \\
\hline $\begin{array}{l}\text { 2. The share of debt on taxes and levies in the } \\
\text { total amount of tax payments }\end{array}$ & 0.25 & 1.25 & +1.0 & $(1-1.25)^{2}=0.0625$ \\
\hline $\begin{array}{l}\text { 3. The share of one's own revenue in the total } \\
\text { volume of revenue }\end{array}$ & 0.93 & 0.93 & - & $(1-0.93)^{2}=0.0049$ \\
\hline 4. The share of tax receipts in the volume of GRP & 0.05 & 0.1 & +0.05 & $(1-0.1)^{2}=0.81$ \\
\hline $\begin{array}{l}\text { 5. The share of funds directed into budgets of } \\
\text { other levels }\end{array}$ & 0.35 & 1.17 & +0.82 & $(1-1.17)^{2}=0.0289$ \\
\hline $\begin{array}{l}\text { 6. The coefficient of covering budget outlays } \\
\text { with tax revenue }\end{array}$ & 0.25 & 0.25 & - & $(1-0.25)^{2}=0.5625$ \\
\hline $\begin{array}{l}\text { 7. The share of outlays on servicing the debt of } \\
\text { the Federation's constituent in the budget outlays } \\
\text { of the Federation's constituent }\end{array}$ & 0.002 & 0.013 & +0.011 & $(1-0.013)^{2}=0.974169$ \\
\hline $\begin{array}{l}\text { 8. The coefficient of the budget's financial } \\
\text { dependence }\end{array}$ & 0.969 & 3.23 & +2.261 & $(1-3.23)^{2}=4.9729$ \\
\hline 9. The level of the region's fiscal capacity & 0.61 & 0.61 & - & $(1-0.61)^{2}=0.1521$ \\
\hline $\begin{array}{l}\text { 10. The ratio between the region's budget deficit } \\
\text { and the volume of revenue not inclusive of } \\
\text { financial support from the federal budget }\end{array}$ & 0.1 & 0.67 & +0.57 & $(1-0.67)^{2}=0.1089$ \\
\hline The integral indicator & & & & 2.772 \\
\hline
\end{tabular}




\section{Results}

Table 6 illustrates the results of calculating the integral indicators of the efficacy of the budgetary/taxation policy of the Republic of Dagestan over the period of 2009-2013.

Table 6. The results of calculating the integral indicators of the efficacy of the budgetary/taxation policy of the Republic of Dagestan over the period of 2009-2013

\begin{tabular}{lll}
\hline Years & Value of integrated assessment & Rating \\
\hline 2009 & 2.861 & 5 \\
2010 & 2.804 & 3 \\
2011 & 2.827 & 4 \\
2012 & 2.771 & 1 \\
2013 & 2.792 & 2 \\
\hline
\end{tabular}

The computation of the rating affords ground to state that by most criteria reflecting the efficacy of formation of revenue and outlays and the balancedeness and sustainability of the regional budget, the most optimum is the policy of 2012. Also, it has been established that of the highest significance to the region's effective budgetary/taxation policy in 2012 were the characteristics reflected below in the indicators ordered by priority of significance for the given period: the coefficient of the budget's financial dependence; the share of outlays on servicing the debt of the Federation's constituent in the outlays of the budget of the Federation's constituent; the share of tax receipts in the volume of GRP; the coefficient of covering budget outlays with tax revenue.

\section{Discussion}

At the present time, there is no single methodological approach towards assessing the efficacy of regions' budgetary/taxation policy. The difference between approaches towards assessing the efficacy of regions' budgetary/taxation policy is associated with different goals set in assessment.

Some authors of the methodology for assessing the efficacy of regions' budgetary/taxation policy mention the indicator but do not provide an economic rationale for their choice (Ushvitsky, 2005, p. 13). Besides, one of the weaknesses of existing methodologies for assessing the efficacy of regions' budgetary/taxation policy is, in our view, that researchers provide a list of private indicators which are both absolute and relative (Merkushov, 2007, p. 18), and it is not specified in the methodology in what way they are taken into account in calculating the integral coefficient which generalizes the private indicators.

As part of another approach, there is a massive list of private coefficients for assessing the integral index of the efficacy of regions' budgetary/taxation policy, which, in our view, is a weakness as well-since a large number of indicators does not increase the accuracy and credibility of the assessment (Krivonosova, 2007, p. 19). The essence of the methodology lies in that the authors suggest ranking regions by the integral index obtained through the multiplication of the private index by the weight and based on the weighted values of the indexes calculating the cumulative index, which, in turn, is joined with different weights into the integral indicator. The weakness of this methodology is, in our view, also in that here weight coefficients, which are determined through the expert method, are assigned twice, which increases the risk of bias in the assessment.

There is a methodology that for assessing the efficacy of budgetary/taxation policy uses efficiency indicators-end effect indicators, immediate result indicators, and resource use indicators. It was proposed by Ye. V. Berezdivina in her work "A Scorecard for the Efficiency of a Budget Planning Entity". Some of these indicators do substantially reflect the state of budget policy as they are directly related to finance, while others are rather of a descriptive nature, and to calculate the third one need statistical information collected across RF constituents and the country as a whole.

Of interest is the audit institution methodology developed by Ye. V. Shipilova, which is about assessing the efficacy of regions' budgetary/taxation policy from the standpoint of checking the credibility of information provided on fulfilling the budget and the degree to which operations on managing the organization's financial/economic activity comport with existing legislation. Also, using this methodology they conduct the assessment of the efficacy and expediency of making managerial decisions and using limited resources. However, the methodology is limited in that it ignores the issue of the quality of life of the region's population, for audit institutions act based on the precondition that there is an infraction. And it can happen that the assessment itself 
will require sizable expenditure, whereas these resources can be used in an alternative way.

There are methodologies using for assessing the efficacy of regions' budgetary/taxation policy universally accepted coefficients, such as the coefficient of the ratio between non-repayable receipts and revenue obtained; the coefficient of regions' budget efficiency; the coefficient of budget debt; the coefficient of budget covering; the coefficient of the population's fiscal security (Igonina, 2003, p. 63). These methodologies are distinguished by being widely used and applied in assessing the region's activity. They characterize the more general trends in the region's activity without getting hung up on more private issues. Their strength is in that they describe the situation in the region's budgetary/taxation sphere most comprehensively.

A detailed analysis of the methodological approaches examined indicates that they focus on just particular aspects and do not give a full-scale assessment of the efficacy of regions' budgetary/taxation policy. Each of them has its own strengths, which are based on clear-cut and logical substantiation of a chosen criterion of efficacy, and weaknesses, which are associated with the impossibility of encompassing the entire group of factors impacting on the efficacy of regions' budgetary/taxation policy.

\section{Conclusion}

The proposed methodology makes it possible to give an integral and structured, in terms of key blocks, assessment of the efficacy of a region's budgetary/taxation policy both over time and through comparison with other regions and increase the validity and accuracy of the assessment for working out practical recommendations. Certain suggestions by the authors may need a more in-depth theoretical investigation, but with all the difficulty of resolving the issues examined in the article, the proposed methodological approach can serve as an efficient toolbox for assessing the efficacy of the budgetary/taxation policy of regions.

\section{Acknowledgements}

This article is being published as part of the project portion of a state assignment (Project Code 1569). The authors extend their gratitude to the Ministry of Education and Science of the Russian Federation for backing the project.

\section{References}

Aliyev, B., \& Suleimanov, M. (2013a). Regional Taxation Policy in the Determinants of Decentralization Processes. Ekonomicheskiy Analiz: Teoriya i Praktika, 40, 47-52.

Aliyev, B., \& Suleimanov, M. (2013b). Strategic Benchmarks of Enhancing Russia's Taxation System. Finansy $i$ Kredit, 42, 43-47.

Berezdivina, Y. (n. d.). A Scorecard for the Efficiency of a Budget Planning Entity. Retrieved from http://www.politanaliz.ru/art_list_90.html

Brennan, G., \& Buchanan, J. (2008). The Power to Tax: Analytical Foundations of a Fiscal Constitution. Cambridge: Cambridge University Press.

Budget Message of the President of the Russian Federation on Budget Policy in 2014-2016.

Budget Strategy for the Period through to 2023. Retrieved from http://www.minfin.ru

Igonina, L. (2007). Municipal Finance. Moscow: Ekonomist.

Kravtsova, N., Magomedova, R., \& Suleimanov, M. (2014). Taxation Decentralization as the Basis of the Formation of a Region's Effective Budgetary/Taxation Policy. Regionalnaya Ekonomika: Teoriya $i$ Praktika, 10, 7-15.

Krivonosova, N. (2007). A Methodology for Assessing Regional Budgetary Policy. Izvestiya Gosudarstvennoy Ekonomicheskoy Akademii, 3.

Laptev, S. (2010). The Fundamentals of the Theory of State Finance. Moscow: YuNITI-DANA.

Major Focus Areas of the Taxation Policy of the Russian Federation for 2014 and for the Target Period of 2015 and 2016. Retrieved from http://www.base.consultant.ru

Merkushov, V. (2007). An Integral Assessment of the Competitiveness of Regions in Strategic Marketing (4th ed.). Saint Petersburg: Piter.

Musaeva, K. (2013). Institutional Aspects of Tax Planning in the Conditions of Reforming of Tax System and Improvement of Tax Management. World Applied Sciences Journal, 27(5), 643-648.

Oates, W. (1972). Fiscal Federalism. N.Y.: Harcourt, Brace, Jovanovich. 
Oates, W. (1999). An Essay on Fiscal Federalism. Journal of Economic Literature, 37, 1120-1149. http://dx.doi.org/10.1257/jel.37.3.1120

Shipilova, Y. (n. d.). Priorities in Assessing the Efficacy of Budgetary Outlays in Administering the External Control of the Regional Budget. Retrieved from http://www.openbudget.karelia.ru

Suleimanov, M. (2013). Reserves of the Growth of the Taxation Potential of the Republic of Dagestan. Regionalnaya Ekonomika: Teoriya i Praktika, 39, 9-13.

Treisman, D. (2004). State Corroding Federalism. Journal of Public Economics, 88, 819-843. http://dx.doi.org /10.1016/S0047-2727(02)00220-7

Ushvitsky, L., \& Parakhina, V. (2005). The Competitiveness of a Region as a New Reality: Its Essence, Methods for Assessing It, and It's Modern State. Sb. Nauch. Tr. SevKavGTU. Ser.: Ekonomika, 1.

\section{Copyrights}

Copyright for this article is retained by the author(s), with first publication rights granted to the journal.

This is an open-access article distributed under the terms and conditions of the Creative Commons Attribution license (http://creativecommons.org/licenses/by/3.0/). 